\title{
Learning Video: Efforts to Improve the Quality of Natural Resource Learning for Elementary School Students
}

\author{
Ni Putu Yogi Sri Kusumawati*, I Nyoman Laba Jayanta², Adrianus I Wayan Ilia \\ Yuda Sukmana ${ }^{3}$
}

1,2,3 Universitas Pendidikan Ganesha, Singaraja, Indonesia

\section{ARTICLE INFO \\ Article history: \\ Received March 20, 2021 \\ Revised March 21, 2021 \\ Accepted June 17, 2021 \\ Available online August 25, 2021}

Kata Kunci:

Sumber Daya Alam, Video

Pembelajaran

Keywords:

Natural Resources, Learning Videos

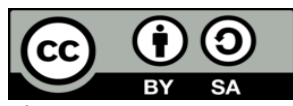

This is an open access article under the CC BY-SA license.

Copyright (C) 2021 by Author.

Published by Universitas Pendidikan Ganesha.

\begin{abstract}
A B S T R A K
Rendahnya hasil belajar siswa didasari oleh kurangnya media pembelajaran yang mampu memotivasi siswa untuk belajar. Oleh sebab itu, perlu dikembangkan media pembelajaran yang dapat meningkatkan motivasi belajar siswa. Penelitian ini bertujuan untuk menghasilkan produk berupa media video pembelajaran pada muatan IPA khususnya materi sumber daya alam. Penelitian ini merupakan penelitian pengembangan Research \& Development yang berpedoman dengan model Borg \& Gall. Subjek dalam penelitian ini adalah media video pembelajaran, dengan validitas media sebagai objek penelitian. Penelitian ini melibatkan satu orang ahli materi pembelajaran, satu orang ahli media pembelajaran, satu orang ahli desain pembelajaran, dan uji lapangan persiapan (satu orang guru dan 6 siswa). Metode pengumpulan data menggunakan angket dan kuisioner yang kemudian dianalisis menggunakan analisis deskriptif kuantitatif. Hasil penelitian ini menunjukan bahwa dari aspek materi pembelajaran, aspek media pembelajaran, dan aspek desain pembelajaran berkualifikasi sangat baik dengan persentase 96,1\%. Dari aspek uji lapangan persiapan media ini berkualifikasi sangat baik dengan persentase 97,4\%. Dapat disimpulkan bahwa media video pembelajaran yang dikembangkan layak digunakan pada muatan IPA khususnya materi sumber daya alam di kelas IV SD. Oleh sebab itu, disarankan untuk menggunakan media video sebagai salah satu alternatif dalam meningkatkan kualitas pembelajaran materi sumber daya alam di kelas IV SD.
\end{abstract}

\section{A B S T R A C T}

The low student learning outcomes are caused by the lack of learning media that can motivate students to learn. Therefore, it is necessary to develop learning media that can increase student learning motivation. This study aims to produce products in the form of learning video media on science content, especially natural resource materials. This research is a Research \& Development research based on the Borg \& Gall model. The subject in this research is learning video media, with the validity of the media as the object of research. This study involved one learning material expert, one instructional media expert, one instructional design expert, and field test preparation (one teacher and six students). The data collection method used questionnaires and questionnaires which were then analyzed using quantitative descriptive analysis. The results of this study indicate that from the aspect of learning materials, aspects of learning media, and aspects of learning design, the qualifications are very good with a percentage of $96.1 \%$. From the aspect of field testing, this media preparation has very good qualifications with a percentage of $97.4 \%$. It was concluded that the learning video media developed was suitable for use in science content, especially natural resource materials in grade IV SD. Therefore, it is recommended to use video media as an alternative in improving the quality of learning natural resource materials in the fourth grade of elementary school.

\section{INTRODUCTION}

Learning is essentially regulating and organizing the environment around students to grow and encourage students to carry out the learning process (Pane \& Dasopang, 2017). Learning objectives are generally emphasized on the mastery of various competencies. Mastery of competence can be seen clearly in student academic achievement (Ventura et al., 2020). Academic achievement is a change in behavioral skills or abilities that can increase over time in learning situations (Indaryati \& Jailani, 2015; Izzaty et al., 2017). If learning is viewed from a systems approach, several elements need to be studied. These elements are students, teachers, learning facilities, resources, and the environment (Nadziroh, 2017). These elements have an important role so that the learning objectives are expected to be achieved properly. Students are one of the components that occupy the main position in the learning process. In the implementation of learning, students are expected to achieve optimally programmed competencies (Lapisa et al., 2017). Another element is the teacher. The teacher is obliged to educate, implement, and 
design learning to achieve competencies as expected. To achieve student competence in learning, the teacher acts as a model, planner, leader, and guide to the learning center (Kirom, 2017; Zein, 2016). Talk about competence. One of the competencies that students must master, especially in the fourth grade of elementary school, is competence related to science content. Science is one of the subjects in schools that can provide roles and experiences for students. Science learning in elementary schools is expected to be a vehicle for students to learn about themselves and their natural surroundings and apply them in their daily lives (Huang et al., 2020). Science learning is not only memorizing but requires understanding concepts (Schiefer et al., 2017). Learning science aims to master complex and meaningful science concepts for students through learning activities (Yadav et al., 2018). The characteristic of science is that it has scientific value, meaning that the truth in science can be proven again by everyone using scientific methods and procedures as previously done by the inventor (Amal \& Kune, 2018).

Based on interviews with fourth-grade teachers of SD Negeri 1 Jinengdalem regarding the problems and needs of learning media in teaching science learning materials in fourth grade, teachers have not fully implemented active, creative, and innovative learning. Students learn more in theory and only rely on textbooks provided at school in teaching and learning activities. Teachers also underutilize the presence of media in the form of LCDs in schools. It impacts the learning process, which results in a lack of student motivation to learn. Students' understanding of one of the materials in the science content especially natural resources is still lacking and affects the fourth-grade students' science learning outcomes at SD Negeri 1 Jinengdalem. Learning motivation is an impulse that arises from within students and outside students to do something. Motivation from within students includes the desire and desire to succeed, the drive to learn, and hopes for student goals. At the same time, the motivation from outside the students includes appreciation, a conducive learning environment, interesting learning activities, and the teacher's efforts in teaching students. The results of previous research say that the obstacles faced in the science learning process are the lack of students understanding with the materials taught by the teacher so that the learning that takes place feels boring and if left continuously will result in not achieving the learning objectives as expected (Awe \& Benge, 2017). With the this problems, it is known that fourthgrade students at SD Negeri 1 Jinengdalem need media that can increase student motivation in learning. Therefore, a science learning video media was developed, which includes natural resource material. Video media contains attractive visuals to increase students' enthusiasm and motivation when participating in learning. Several studies have found that video learning media is generally suitable for use in learning. The fourth-grade elementary school video-based media developed effectively improves learning achievement (Fadhli \& Ponorogo, 2018). Subsequent research on the development of video media for learning mathematics for basic competencies, the size of statistical data presentation with the ASSURE model, states that the media developed is suitable for learning media in the twelfth grade in the second semester (Purwanti, 2015). Next, the development of instructional video media to improve motivation and cognitive learning outcomes of fourth-grade elementary school students showed that instructional video media were suitable for use according to material experts and media experts with good categories (Titi Suryansyah, 2016). The learning video media produced in these studies have shown good results and can be used in the learning process.

Learning video media developed for fourth-grade students at SD Negeri 1 Jinengdalem can help teachers learn. Learning media are intermediary communication components in the form of tools and materials used in the learning process to gain knowledge (Agustiningsih, 2015; Muhson, 2010). The main function of learning media is as a teaching aid that also influences the climate, conditions, and learning environment arranged and created by the teacher (Balandin et al., 2010; Tafonao, 2018). Furthermore, video is a media that contains audio and visual elements, so it is called audiovisual media. With the audiovisual media, students can see real actions from what is contained in the media. It can stimulate student learning motivation (Busyaeri et al., 2016; Purwanti, 2015). Video media students are expected to be motivated in learning and not quickly feel bored when participating in learning. Developing this video learning media is that its use can be sustainable, easy and practical, and more varied (Wisada et al., 2019). With science learning video media, it is expected to attract students' interest in learning science, especially natural resource material. So that students do not only read the material in the textbook but are interspersed with learning videos that discuss natural resources, which students can directly observe students through video shows. This research aims to develop science learning video media to explain natural resource material for fourth-grade students of SD Negeri 1 Jinengdalem. Theoretical and empirical considerations include video media that can be used as an independent learning resource. That emphasizes individual initiative in learning where someone takes the initiative without the help of others. Help teachers in choosing and making science learning more effective, accelerate mastery of natural resource materials, improves interest and enthusiasm for student learning to help improve student learning outcomes. The condition of effective teaching and learning is the interest and attention of 
students in learning (Sirait, 2016). Interest is a relatively permanent trait in a person and has a very large influence on learning because, with interest, someone will do something that interests him. On the other hand, it is impossible to carry out an activity (Song \& Vermunt, 2021). This study aims to produce products in the form of learning video media on science content, especially natural resource materials. Video media is expected to increase students' interest in learning to understand the material on the science content increases.

\section{METHOD}

This research is a research and development research and development (R\&D). Research and Development Research and Development (R\&D) is a method that aims to produce certain products and test the validity and effectiveness of these products in their application (Hanafi, 2017). The development model used is the Borg \& Gall model consisting of 10 stages presented in Figure 1.

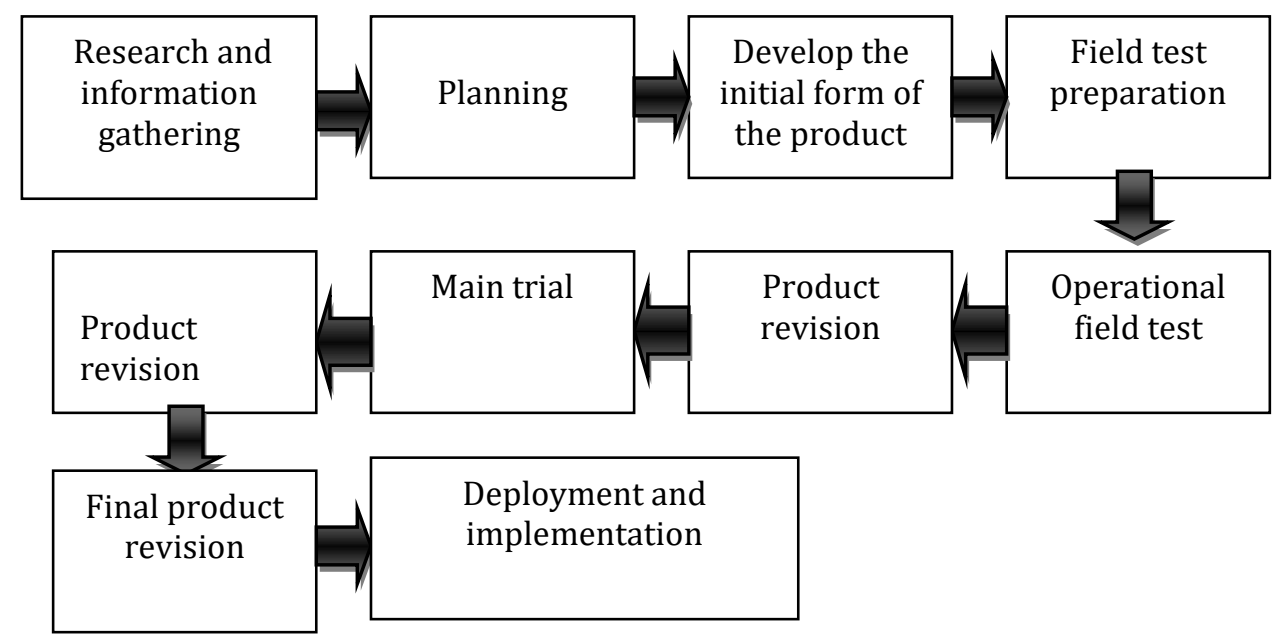

Figure 1. Stages of the Borg \& Gall model

In this study, the data collection stage reached the stage of preparing and revising the product field test. It happened because of the COVID-19 pandemic outbreak, which made all schools conduct online learning and did not allow researchers to go out and conduct research on a large scale and limited research time. The research subjects at the product validation stage in this development research include one material expert, one media expert, one learning design expert, and field test preparation (one teacher and six students at SD Negeri 1 Jinengdalem). The data taken in this study is quantitative. The data describes the quality of the product, which includes aspects of content and instructional media implementation instructions. In the descriptive analysis, the quantitative data obtained are searched for the average score and then converted based on a five-scale conversion table. In detail, the data was collected by grouping it into two parts. The first part is the data taken from evaluating the first stage in data from the review results from content experts and subject experts. The second part is the data taken from the second stage of evaluation, the data from the review of the preparatory field test.

The data collection instrument is a tool used by researchers in data collection. The instrument used in this research is a questionnaire in questions related to video-based learning media (Yogi, 2014). The questionnaire contains questions related to the feasibility and needs of video-based learning media. Questionnaires are used to collect data on the results of reviews from content experts and subject experts, field test preparation. The questionnaire in this study is to obtain data regarding the feasibility of the product being developed to produce a high-quality product. Testing of test kits/instruments is intended to assess the ability of the test kits as a whole (Agusta et al., 2012). The learning outcomes instrument must go through an expert test to qualify as a good instrument. The validity sought is content validity. To determine the validity of the content of the video-based learning media, a rater assessment or moderator technique was used. Two instrument experts in determining the validity of the display were asked as raters to determine the content validity of the learning video instrument. The results of the assessments of the two raters were analyzed using Gregory's technique which was then substituted into $2 \mathrm{x} 2$ crosstabulation (Iskandar \& Rizal, 2018). The design of the data collection instrument grid in this development research is presented in Tables 1,2 , and 3. 
Table 1. Learning Media Expert Instruments

\begin{tabular}{cll}
\hline No & \multicolumn{1}{c}{ Aspect } & \multicolumn{1}{c}{ Number } \\
\hline 1 & Display & $1,2,3$, and 4 \\
2 & Attractiveness and Compatibility & $5,6,7,8,9$, dan 10 \\
3 & Product Packaging & 11 and 12 \\
\hline
\end{tabular}

Table 2. Content Expert Instruments

\begin{tabular}{cll}
\hline No & \multicolumn{1}{c}{ Aspect } & \multicolumn{1}{c}{ Number } \\
\hline 1 & Suitability of learning materials with learning objectives & 1, dan 2 \\
2 & Material characteristics of natural resources & $3,4,5,6,7,8,9$, and10 \\
\hline
\end{tabular}

Table 3. Learning Design Expert Instruments

\begin{tabular}{|c|c|c|}
\hline No & Aspect & Number \\
\hline 1 & $\begin{array}{l}\text { The suitability of the media delivery strategy with the characteristics } \\
\text { of students }\end{array}$ & 1 and 2 \\
\hline 2 & The suitability of the material with the learning objectives & 3,4, and 5 \\
\hline 3 & The suitability of the method with the learning objectives & $6,7,8,9$, and 10 \\
\hline
\end{tabular}

The instrument validity test of content experts, learning media experts, and learning design experts showed that the instrument was suitable for testing the results of developing natural resource science learning video media for fourth-grade students of SD Negeri 1 Jinengdalem be tested further. This study collects data using quantitative descriptive analysis techniques that describe product development results in learning video media. Testing the validity and product feasibility to be implemented to develop natural resource science learning video media. This analysis technique is used to process the data obtained through a questionnaire in the form of a descriptive percentage (Tegeh \& Jampel, 2017). Provisions are used to provide meaning and decision-making on natural resource science learning video media, as presented in Table 4.

B Achievement Rate Conversions on a five scale

\begin{tabular}{cll}
\hline Achievement Level (\%) & \multicolumn{1}{c}{ Qualification } & \multicolumn{1}{c}{ Description } \\
\hline $90-100$ & Very good & No need to revise \\
$75-89$ & Good & Slightly revised \\
$65-79$ & Enough & Revised sufficiently \\
$55-64$ & Less & Many things have been revised \\
$1-54$ & Bad & Repeated in making products \\
\hline
\end{tabular}

(Tegeh \& Jampel, 2017).

\section{RESULT AND DISCUSSION}

Result

This study developed a natural resource video media for fourth-grade students at SD Negeri 1 Jinengdalem. Product development was carried out using the Borg \& Gall model. The research and information collection stage showed that students' learning motivation at SD Negeri 1 Jinengdalem is still not optimal. Due to the lack of innovative media that can encourage students' enthusiasm in learning, especially in science content, interesting media were needed and can increase student motivation to learn. Furthermore, the planning stage begins by choosing one of the materials or topics in the science content, natural resource material, then designing flowcharts and storyboards used as guidelines in making video media. At the stage of developing the preliminary form of the product, validation was carried out by experts. Furthermore, at the preparatory field test stage, product trials were carried out to SD Negeri 1 Jinengdalem by involving teachers and students. Furthermore, at the product revision stage, revising the initial trial's shortcomings obtained from the validation test results from the experts and the preparation field test. The design of the video media product produced can be seen in Figures 2 and 3.

This instructional video media development has gone through a validity test by learning material expert tests, learning media expert tests, learning design expert tests, and preparatory field tests (teachers and students of SD Negeri 1 Jinengdalem). The results of the product validity test of the developed science learning video media can be seen in table 2 about the results of the product validity test. 


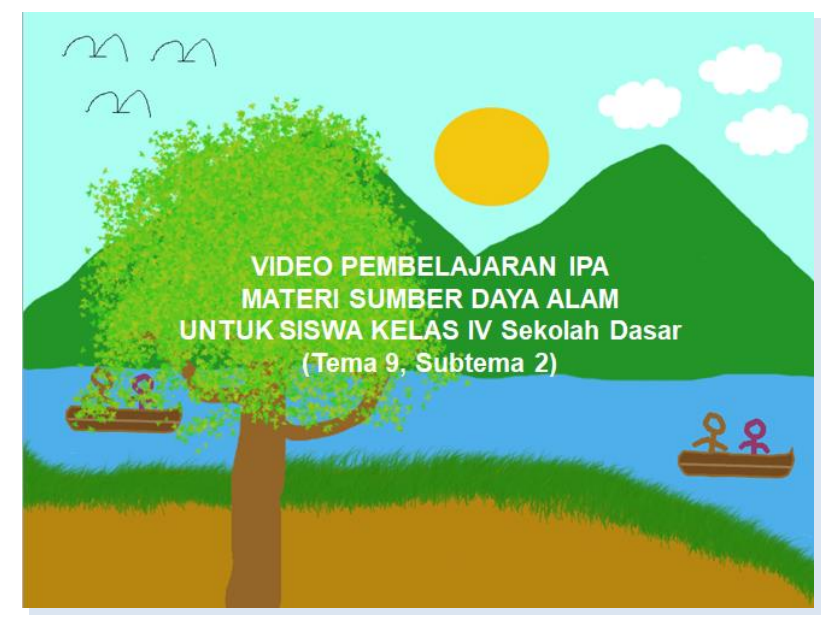

Figure 2. Video Cover Display

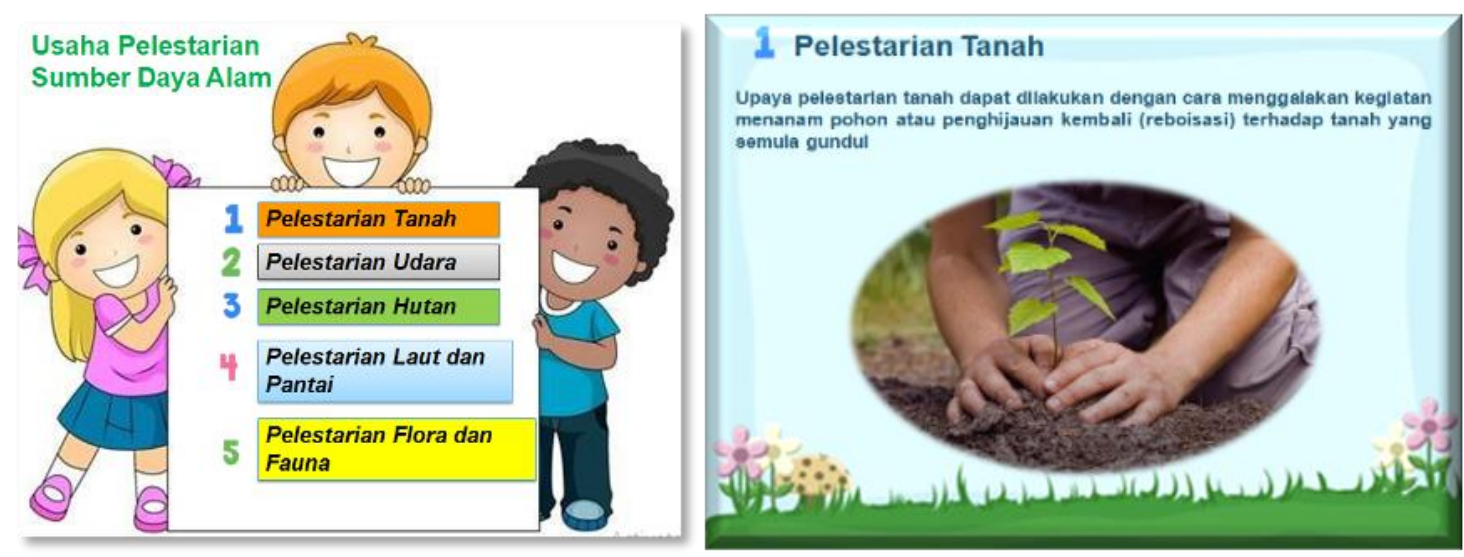

Figure 3. Video Content Display

Table 2. Product Validity Test Results

\begin{tabular}{clcc}
\hline No & Learning Video Media Trial Subject & Validity Results & Description \\
\hline 1. & Material Expert Test & $98 \%$ & Very good \\
2. & Learning Media Expert Test & $96,3 \%$ & Very good \\
3. & Learning Design Expert Test & $94 \%$ & Very good \\
4. & Field Test Preparation & $97,4 \%$ & Very good \\
\hline
\end{tabular}

Experts provided some comments, suggestions, and inputs. These suggestions and inputs are used to improve or revise the learning video media products developed are better.

\section{Discussion}

Based on the research that has been done, a product has been produced, the science learning video media on natural resource materials for fourth-grade students of SD Negeri 1 Jinengdalem. Based on the analysis carried out on the validity test carried out on the media aspect, content aspect, and learning design aspect, it is known that this science learning video media is valid and suitable for learning. At the research and information collection stage on the Borg \& Gall model, a problem was found. The lack of motivation to learn for fourth graders at SD Negeri 1 Jinengdalem because, in the learning process, the teacher only uses textbooks to look monotonous, and students tend to feel bored quickly. Based on this, media is needed that can increase students' interest in learning. It impacts students' understanding of a lesson (Amjah, 2014; Fryer, 2015). Interest can create enthusiasm in carrying out activities so that the goals of these activities can be achieved (Freischlag et al., 2019). Great interest is the capital to achieve learning goals (Deng et al., 2016). To achieve learning objectives, every teacher must understand and think about learning strategies applied during class learning (Anand et al., 2021; Biwer et al., 2020). Learning strategy is one of the important elements to be understood by the teacher. Learning strategies are prepared based on a certain approach. 
The approach is a set of systematically used insights as a basis for thinking in determining strategies, methods, and techniques or procedures in achieving certain results according to predetermined goals (Takase \& Yoshida, 2021; Tho et al., 2020). Accuracy in choosing a strategy allows implementing the selected methods to realize and create conducive and fun learning conditions. Students feel it is easier to realize the expected learning outcomes (Li et al., 2020). Therefore, learning video media were developed to increase students' motivation and interest in learning. Learning strategies using video media are a fun source of learning and can encourage students' interest in learning to absorb learning materials well (Hui et al., 2021). Learning media helps convey the material given by the teacher to students (Krissandi, 2018). As a teacher, the teacher is tasked with teaching his students and must prepare interesting learning tools (Sholihin et al., 2020).

Furthermore, it begins by choosing one of the materials or topics in the science content in the fourth grade of elementary school at the planning stage. The material chosen is natural resource material. Natural resources are all things that come from nature that humans can use to meet their needs (Sallata, 2015). Natural resources are a collection of diverse living and non-living things that can be used for human life (Ningsih \& Mardhatillah, 2016). Then design a scenario for making video media that begins with compiling flowcharts and storyboards used as guidelines for making the products developed. The video is designed through the Microsoft PowerPoint application and the android application, VN Video Editor. At the stage of developing the preliminary form of the product, validation is carried out by experts who provide suggestions for product improvement. In improving the product, you will get good quality learning media to significantly influence the teaching and learning process (Dwijayani, 2019; Qomariah, 2016). Good learning media will make effective learning media used during the learning process (Asyhari \& Silvia, 2016). Furthermore, at the preparatory field test stage, product trials were carried out to SD Negeri 1 Jinengdalem by involving teachers and students. The next stage of product revision is to revise the shortcomings in the initial trial obtained from the validation test results from the experts and the preparation field test. From the expert tests that have been carried out, there are several important things to observe in developing valid learning video media for learning, especially science learning content for fourth grade elementary schools. These things include, the presentation of the material on the video in accordance with the characteristics of the growth and development of students, the material in the media is equipped with concrete examples, the material presented on the video is systematic and in the order of the learning objectives so that it is easily understood by students, grammar and sentences according to the characteristics and cognitive level of students.

Fourth graders are generally in the age range of 10-11 years. Characteristics of development at this age are physically in the game. They have the drive and mental ability to understand concepts, logic, truth through symbols with certain meanings (Trianingsih, 2016). Generally, at this age, students will be interested in interesting visuals (Abdel-Hamid, 2021). Technological advances such as the presence of video media in learning can provide a lot of stimulus to students because of the audiovisual nature of the picture (N. Fitriyani, 2019). In this regard, the material presented on video media is adjusted to the characteristics of students. The presentation of the material is packaged in the form of animations, images, and colors that are attractive and comfortable for students to see (Kramer et al., 2020). Therefore, the learning video media developed is suitable for students, especially in the science content, which includes material about natural resources studied in the fourth grade of elementary school.

In addition to the material that is packaged attractively, it must also be equipped with concrete examples. Still, at the level of cognitive development of students, SD/MI age is in the concrete operational stage (7-11 years), which is still thinking and understanding things from real things that exist in their environment so that the presence of these concrete examples supports students' understanding. On the material being studied (Daryanto, 2010). The material presented in the video is easily understood by students clearly because sentence structures support the media according to students' cognitive level. After all, the sentences in the video are arranged briefly and systematically. In addition, the sentences used are effective so that the material presented can be easily understood by students (D. Fitriyani, 2015). An effective sentence is a sentence that can express the author's ideas appropriately so that they can be understood by the reader correctly (Apriani et al., 2020; Mesterianti et al., 2019). Effective, in this case, is the size of the sentence that can generate ideas or thoughts in the listener or reader. In other words, an effective sentence is a sentence that can represent the thoughts of the author or speaker precisely so that the listener or reader can understand these thoughts easily, clearly, and completely as intended by the author or speaker (Widiyarto, 2017). In creating nuances of meaning from what you want to convey to the media, diction or choice of words in the presentation of the material plays an important role (Surianti et al., 2019). The sentences in this video are designed to be simple, using the right terms and commonly used by students. So that the grammar and sentences presented affect the effectiveness of the media. The correct language is a language that follows the rules of standard language, both the rules for written 
standard language and spoken standard language, which aims to follow good and correct language rules and refers to a variety of languages that meet the requirements of linguistic rules (Puspitasari, 2017). The language spoken is usually in the form of the standard language (Suminar, 2016).

In addition, the developed learning video media has advantages in terms of visuals. Images on video media are visible with HD quality so that they look attractive because clear colors and shapes support them. Color is one of the elements of beauty in art and design is a visual element that determines the attractiveness of the media (Yetri \& Pariaman, 2014). Therefore, the video media developed is expected to be useful for students when learning about science content. Based on some of the things above to develop instructional video media, video media is expected to attract students' interest and motivation to learn, especially natural resource material science content. Media in education is needed as an intermediary to deliver messages to minimize failures during the communication process (Hakim, 2018). The selection of learning media in videos is expected to assist teachers in delivering material on science content, especially natural resource materials.

This development research has limitations. The subject is only limited to fourth-grade students of SD Negeri 1 Jinengdalem. The validity test uses a content expert, a media expert, and an instructional design expert. This research is only limited to improving the science learning process with natural resource materials. The resulting product is a science learning video with natural resource materials. In addition, the stages carried out on the Borg \& Gall model only reached the revision stage of the main product. The covid19 outbreak did not allow researchers to research on a large scale and limited research time. Based on this, it is expected that other researchers can continue their research to the final product revision. They can find out the effectiveness of the natural resource science learning video media for fourth-grade elementary school students to increase students' motivation and interest in learning.

\section{CONCLUSION}

This development research resulted in a product in the form of a science learning video media developed using the Borg \& Gall model for fourth-grade elementary school students with very good qualifications. The advantages of this learning video media lie in the presentation of complete natural resource material and grammar and sentences that are arranged briefly and systematically. Then the learning video media with natural resource material is declared suitable for use in science content in the fourth grade of SD Negeri 1 Jinengdalem.

\section{REFERENCES}

Abdel-Hamid, L. (2021). Retinal Image Quality Assessment Using Transfer Learning: Spatial Images Vs. Wavelet Detail Subbands. Ain Shams Engineering Journal, xхxx. https://doi.org/10.1016/j.asej.2021.02.010.

Agusta, S., Mulia, T., \& Sidik, M. (2012). Instrumen Pengujian Buta Warna Otomatis. Jurnal Ilmiah Elite Elektro, 3(1),

$15-22$. http://pnj.ac.id/upload/artikel/files/elektro/Sofiar\%20Agusta,\%20Tony\%20Mulia\%20dan\%20 M.Sidik.pdf.

Agustiningsih, A. (2015). Video sebagai Alternatif Media Pembelajaran dalam Rangka Mendukung Keberhasilan Penerapan Kurikulum 2013 di Sekolah Dasar. PEDAGOGIA: Jurnal Pendidikan, 4(1), 50. https://doi.org/10.21070/pedagogia.v4i1.72.

Amal, A., \& Kune, S. (2018). Peranan Pembelajaran IPA Berorientasi POE (Predict, Observe, Explain) untuk Meningkatkan Keterampilan Proses dan Hasil Belajar di Sekolah Dasar. Prosiding Seminar Nasional Pendidikan, 1(1), 607-620. https://jurnal.umj.ac.id/index.php/SNP/article/view/2927.

Amjah, D. Y. P. H. (2014). A Study of Teachers' Strategies so Develop Students' Interest towards Learning English as a Second Language. Procedia - Social and Behavioral Sciences, 134, 188-192. https://doi.org/10.1016/j.sbspro.2014.04.238.

Anand, N., Pujar, S., \& Rao, S. (2021). A heutagogical interactive Tutorial Involving Fishbowl with Fish Battle and Round Robin Brainstorming: A Novel Syndicate Metacognitive Learning Strategy. Medical Journal Armed Forces India, 77, S73-S78. https://doi.org/10.1016/j.mjafi.2020.12.003.

Apriani, H., Rahman, F., \& Hidayat, R. (2020). Pengaruh Penguasaan Kalimat Efektif terhadap Kemampuan Menulis Karangan Narasi pada Siswa. Imajeri: Jurnal Pendidikan Bahasa Dan Sastra Indonesia, 2(2), 119-128. https://doi.org/10.22236/imajeri.v2i2.5083.

Asyhari, A., \& Silvia, H. (2016). Pengembangan Media Pembelajaran Berupa Buletin dalam Bentuk Buku Saku untuk Pembelajran IPA Terpadu. Jurnal Ilmiah Pendidikan Fisika Al-Biruni, 5(1), 1-13. https://doi.org/10.24042/jpifalbiruni.v5i1.100. 
Awe, E. Y., \& Benge, K. (2017). Hubungan Antara Minat Dan Motivasi Belajar Dengan Hasil Belajar Ipa Pada Siswa Sd. Journal of Education Technology, 1(4), 231. https://doi.org/10.23887/jet.v1i4.12859.

Balandin, S., Oliver, I., Boldyrev, S., Smirnov, A., Shilov, N., \& Kashevnik, A. (2010). Multimedia Services on Top of M3 Smart Spaces. Proceedings - 2010 IEEE Region 8 International Conference on Computational Technologies in Electrical and Electronics Engineering, SIBIRCON-2010, 13(2), 728732. https://doi.org/10.1109/SIBIRCON.2010.5555154.

Biwer, F., Egbrink, M. G. A. oud., Aalten, P., \& de Bruin, A. B. H. (2020). Fostering Effective Learning Strategies in Higher Education - A Mixed-Methods Study. Journal of Applied Research in Memory and Cognition, 9(2), 186-203. https://doi.org/10.1016/j.jarmac.2020.03.004.

Busyaeri, A., Udin, T., \& Zaenudin, A. (2016). Pengaruh Penggunaan Video Pembelajaran terhadap Peningkatan Hasil Belajar Mapel IPA di Min Kroya Cirebon. Al Ibtida: Jurnal Pendidikan Guru MI, 3(1), 116-137. https://doi.org/10.24235/al.ibtida.snj.v3i1.584.

Daryanto. (2010). Pengaruh Media Pembelajaran Berbasis Multimedia terhadap Motivasi dan Manusia Studi Eksperimen pada Siswa Kelas V MI Miftahul Huda Pandantoyo. Pengaruh Media Pembelajaran Berbasis Multimedia, 16, 1-77. http://ejournal.iaintulungagung.ac.id/index.php/dinamika/article/download/139/114.

Deng, L., Connelly, J., \& Lau, M. (2016). Interest-Driven Digital Practices of Secondary Students: Cases of Connected Learning. Learning, Culture and Social Interaction, 9, 45-54. Https://Doi.Org/10.1016/j.lcsi.2016.01.004.

Dwijayani, N. M. (2019). Development of Circle Learning Media to Improve Student Learning Outcomes. Journal of Physics: Conference Series, 1321(2), 171-187. https://doi.org/10.1088/17426596/1321/2/022099.

Fadhli, M., \& Ponorogo, U. M. (2018). Pengembangan Media Pembelajaran Berbasis Video Kelas IV. Jurnal Dimensi Pendidikan dan Pembelajaran, 3(1). https://doi.org/10.24269/dpp.v3i1.157.

Fitriyani, D. (2015). Penguasaan Kalimat Efektif dan Penguasaan Diksi dengan Kemampuan Menulis $\begin{array}{llllll}\text { Eksposisi pada Siswa SMP. Jurnal Pesona, } & 137 .\end{array}$ https: //ejournal.umpri.ac.id/index.php/pesona/article/view/109.

Fitriyani, N. (2019). Pengembangan Media Pembelajaran Audio-Visual Powtoon tentang Konsep Diri dalam Bimbingan Kelompok untuk Peserta Didik Sekolah Dasar. Jurnal Tunas Bangsa, 6(1), 104114. https://ejournal.bbg.ac.id/tunasbangsa/article/view/950.

Freischlag, K., Ji, K., Kamyszek, R. W., Leraas, H. J., Olivere, L. A., Gefter, L., Mann, B., Migaly, J., \& Tracy, E. T. (2019). Health Career Academy: Addition of a Surgical Case-Based Learning Curriculum Captures the Interest of High School Students. Journal of Surgical Education, 76(2), 401-407. https: //doi.org/10.1016/j.jsurg.2018.07.016.

Fryer, L. K. (2015). Predicting Self-Concept, Interest, and Achievement for First-Year Students: The Seeds of Lifelong Learning. Learning and Individual Differences, 38, 107-114. https://doi.org/10.1016/j.lindif.2015.01.007.

Hakim, L. (2018). Pengembangan Media Pembelajaran Pai Berbasis Augmented Reality. Lentera Pendidikan: Jurnal Ilmu Tarbiyah dan Keguruan, 21(1), 59-72. https://doi.org/10.24252/lp.2018v21n1i6.

Hanafi. (2017). Konsep Penelitian R \& D dalam Bidang Pendidikan. Saintifika Islamica: Jurnal Kajian Keislaman, 4(2),

130. http://www.jurnal.uinbanten.ac.id/index.php/saintifikaislamica/article/view/1204.

Huang, S. Y., Kuo, Y. H., \& Chen, H. C. (2020). Applying Digital Escape Rooms Infused with Science Teaching in Elementary School: Learning Performance, Learning Motivation, and Problem-Solving Ability. Thinking Skills and Creativity, 37(129), 100681. https://doi.org/10.1016/j.tsc.2020.100681.

Hui, L., de Bruin, A. B. H., Donkers, J., \& van Merriënboer, J. J. G. (2021). Stimulating the Intention to Change Learning Strategies: The Role of Narratives. International Journal of Educational Research, 107(January). https://doi.org/10.1016/j.ijer.2021.101753.

Indaryati, I., \& Jailani, J. (2015). Pengembangan Media Komik Pembelajaran Matematika Meningkatkan Motivasi dan Prestasi Belajar Siswa Kelas V. Jurnal Prima Edukasia, 3(1), 84-96. https://doi.org/10.21831/jpe.v3i1.4067.

Iskandar, A., \& Rizal, M. (2018). Analisis Kualitas Soal di Perguruan Tinggi Berbasis Aplikasi TAP. Jurnal Penelitian dan Evaluasi Pendidikan, 22(1), 12-23. https://doi.org/10.21831/pep.v22i1.15609.

Izzaty, R. E., Ayriza, Y., Setiawati, F. A., \& Amalia, R. N. (2017). Prediktor Prestasi Belajar Siswa Kelas 1 Sekolah Dasar. Jurnal Psikologi, 44(2), 153. https://doi.org/10.22146/jpsi.27454.

Kirom, A. (2017). Peran Guru dan Peserta Didik dalam Proses Pembelajaran Berbasis Multikultural. Al Murabbi, 3(1), 69-80. http://jurnal.yudharta.ac.id/v2/index.php/pai/article/view/893.

Kramer, C., König, J., Strauß, S., \& Kaspar, K. (2020). Classroom Videos or Transcripts? A Quasi- 
Experimental Study to Assess the Effects of Media-Based Learning on Pre-Service Teachers' Situation-Specific Skills of Classroom Management. International Journal of Educational Research, 103(June), 101624. https://doi.org/10.1016/j.ijer.2020.101624.

Krissandi, A. D. S. (2018). Pengembangan Video Tematik Sebagai Pengantar Pembelajaran Kurikulum 2013 di Sekolah Dasar. Premiere Educandum : Jurnal Pendidikan Dasar dan Pembelajaran, 8(1), 68. https://doi.org/10.25273/pe.v8i1.2233.

Lapisa, R., Basri, I. Y., Arif, A., \& Saputra, H. D. (2017). Peningkatan Kompetensi Siswa melalui Pelatihan Auto Cad. INVOTEK: Jurnal Inovasi Vokasional dan Teknologi, 17(2), 119-126. https://doi.org/10.24036/invotek.v17i2.82.

Li, G., Yang, M., Zhang, Y., Grace, J., Lu, C., Zeng, Q., Jia, Y., Liu, Y., Lei, J., Geng, X., Wu, C., Lei, G., \& Chen, Y. (2020). Comparison Model Learning Methods for Methane Emission Prediction of Reservoirs on a Regional Field Scale: Performance and Adaptation of Methods with Different Experimental $\begin{array}{llll}\text { Datasets. Ecological } & \text { Engineering, } & 105990 .\end{array}$ https: //doi.org/10.1016/j.ecoleng.2020.105990.

Mesterianti, M., Simarmata, M. Y., \& Firtawati, S. (2019). Penerapan Model Think Talk Write untuk Meningkatkan Keterampilan Menulis bagi Siswa Sekolah Menengah Pertama. Edukasi: Jurnal Pendidikan, 17(1), 98. https://doi.org/10.31571/edukasi.v17i1.1083.

Muhson, A. (2010). Pengembangan Media Pembelajaran Berbasis Teknologi Informasi. Jurnal Pendidikan Akuntansi Indonesia, 8(2). https://doi.org/10.21831/jpai.v8i2.949.

Nadziroh, F. (2017). The Analisa Efektifitas Sistem Pembelajaran Berbasis E-Learning. Journal of Computer Science and Visual Communication Design, 2(1), 14. https://journal.unusida.ac.id/index.php/jik/article/view/28.

Ningsih, W., \& Mardhatillah. (2016). Penerapan Media Audio-Visual terhadap Keaktifan pada Materi Hubungan antara Sumber Daya Alam dengan Lingkungan Siswa Kelas IV SD Negeri Pasi Teungoh Kecamatan Kaway XVI. Jurnal Ilmiah Pendidikan Guru Sekolah Dasar, 2, 1-14. https://www.ejournal.stkipbbm.ac.id/index.php/pgsd/article/view/154.

Pane, A., \& Darwis Dasopang, M. (2017). Belajar dan Pembelajaran. FITRAH:Jurnal Kajian Ilmu-Ilmu Keislaman, 3(2), 333. https://doi.org/10.24952/fitrah.v3i2.945.

Purwanti, B. (2015). Pengembangan Media Video Pembelajaran. Jurnal Kebijakan dan Pengembangan Pendidikan, 3(1), 42-47. https://ejournal.umm.ac.id/index.php/jkpp/article/view/2194.

Puspitasari, A. (2017). Menumbuhkan Bahasa Indonesia yang Baik dan Benar dalam Pendidikan dan Pengajaran. Tamaddun, 16(2), 81-87. https://doi.org/10.33096/tamaddun.v16i2.55.

Qomariah, S. S. (2016). Kualitas Media Pembelajaran, Minat Belajar, dan Hasil Belajar Siswa. Pendidikan Ekonomi dan Bisnis, 4(1), 33-47. http://journal.unj.ac.id/unj/index.php/jpeb.

Sallata, M. K. (2015). Konservasi dan Pengelolaan Sumber Daya Air Berdasarkan Keberadaannya sebagai Sumber Daya Alam. Info Teknis EBONI, 12(1), 75-86. http://balithutmakassar.org/wpcontent/uploads/2014/11/7_Konservasi-Air-berdasarkan-SDA_Info-Teknis-Eboni-Vol-12-No-12015.pdf.

Schiefer, J., Golle, J., Tibus, M., Trautwein, U., \& Oschatz, K. (2017). Elementary School Children's Understanding of Science: The Implementation of an Extracurricular Science Intervention. $\begin{array}{llll}\text { Contemporary Educational } & \text { Psychology, }\end{array}$ https: //doi.org/10.1016/j.cedpsych.2017.09.011.

Sholihin, M., Sari, R. C., Yuniarti, N., \& Ilyana, S. (2020). A New Way of Teaching Business Ethics: The Evaluation of Virtual Reality-Based Learning Media. International Journal of Management Education, 18(3), 100428. https://doi.org/10.1016/j.ijme.2020.100428.

Sirait, E. D. (2016). Pengaruh Minat Belajar terhadap Prestasi Belajar Matematika. Formatif: Jurnal Ilmiah Pendidikan MIPA, 6(1), 35-43. https://doi.org/10.30998/formatif.v6i1.750.

Song, Y., \& Vermunt, J. D. (2021). A Comparative Study of Learning Patterns of Secondary School, High School and College Students. Studies in Educational Evaluation, 68 (January 2020), 100958. https: //doi.org/10.1016/j.stueduc.2020.100958.

Suminar, R. P. (2016). Pengaruh Bahasa Gaul terhadap Penggunaan Bahasa Indonesia Mahasiswa Unswagati. Logika, 18(3), 114-119. www.jurnal.unswagati.ac.id.

Surianti, S., Akhir, M., \& Nojeng, A. (2019). Tindak Tutur Ilokusi sebagai Media Penyampaian Pesan Sosial pada Iklan Layanan Masyarakat. Celebes of Linguistics Journal,1(2), 11-18. http://journal.lldikti9.id/linguistik/article/view/398.

Tafonao, T. (2018). Peranan Media Pembelajaran dalam Meningkatkan Minat Belajar Mahasiswa. Jurnal Komunikasi Pendidikan, 2(2), 103. https://doi.org/10.32585/jkp.v2i2.113.

Takase, M., \& Yoshida, I. (2021). The Relationships between the Types of Learning Approaches Used by Undergraduate Nursing Students and Their Academic Achievement: A Systematic Review and 
Meta-Analysis. Journal of Professional Nursing. https://doi.org/10.1016/j.profnurs.2021.06.005. Tegeh, M., \& Jampel, N. (2017). Metode Penelitian Pengembangan. Universitas Pendidikan Ganesha.

Tho, N. D., Trang, N. T. M., \& Gregory, S. (2020). Positivity and Quality of College Life of Business Students: The Mediating Role of Learning Approaches. Studies in Educational Evaluation, 66(September 2019), 100908. https://doi.org/10.1016/j.stueduc.2020.100908.

Titi Suryansyah. (2016). Pengembangan Video Pembelajaran untuk Meningkatkan Motivasi dan Hasil Belajar Kognitif Siswa Kelas IV SD. Jurnal Prima Edukasia, 4(2), 166-176. https://journal.uny.ac.id/index.php/jpe/article/view/14288/pdf.

Trianingsih, R. (2016). Pengantar Praktik Mendidik Anak Usia Sekolah Dasar. Al Ibtida: Jurnal Pendidikan Guru MI, 3(2), 197. https://doi.org/10.24235/al.ibtida.snj.v3i2.880.

Ventura, A. C., Scheuer, N., \& Pozo, J. I. (2020). Elementary School Children's Conceptions of Teaching and Learning to Write as Intentional Activities. Learning and Instruction, 65(September 2019), 101249. https://doi.org/10.1016/j.learninstruc.2019.101249.

Widiyarto, S. (2017). Pengaruh Minat Belajar dan Pemahaman Kalimat terhadap Kemampuan Menulis Kalimat Efektif. MENDIDIK: Jurnal Kajian Pendidikan dan Pengajaran, 3(2), 169-177. http://ejournal.id/jm/index.php/mendidik/article/view/112.

Wisada, P. D., Sudarma, I. K., \& Yuda S, A. I. W. I. (2019). Pengembangan Media Video Pembelajaran Berorientasi Pendidikan Karakter. Journal of Education Technology, 3(3), 140. https://doi.org/10.23887/jet.v3i3.21735.

Yadav, V. K., Srivastava, N., Ghosh, S. S., Srikar, P. T., \& Subhalakshmi, K. (2018). Science Objectives of the Magnetic Field Experiment Onboard Aditya-L1 Spacecraft. Advances in Space Research, 61(2), 749-758. https://doi.org/10.1016/j.asr.2017.11.008.

Yetri, Y. H. (2014). Meningkatkan Kemampuan Mengenal Warna melalui Permainan Finger Painting bagi Anak Tunagrahita Ringan.Jurnal Penelitian Pendidikan Khusus, 3(1), 227-233. http://ejournal.unp.ac.id/index.php/jupekhu/article/view/3064.

Yogi, M. (2014). Instrumen Penelitian Kualitatif, Kuantitatif, dan Pengembangan. Implementation Science, 39(1), 1-24. http://journal.stainkudus.ac.id/index.php/equilibrium/article/view/1268/1127.

Zein, M. (2016). Peran Guru dalam Pengembangan Pembelajaran. Jurnal Inspiratif Pendidikan, 5(2), 274285. http://103.55.216.56/index.php/Inspiratif-Pendidikan/article/view/3480. 